\title{
Geochemistry of metavolcanic rocks of the Ross Island and Ingalls Head formations, Grand Manan Island, New Brunswick
}

\author{
Georgia Pe-Piper and Begashaw Wolde \\ Department of Geology, Saint Mary's University, Halifax, NS B3H 3C3, Canada
}

Date Received: September 29, 2000

Date Accepted: December 6, 2000

\begin{abstract}
Southeastern Grand Manan Island consists of explosive and effusive volcanic rocks of the Ross Island and Ingalls Head formations that include syn-eruptive sediments and hyaloclastites. Lavas are commonly amygdaloidal and/or microporphyritic with phenocrysts of feldspar and, more rarely, pyroxene or quartz, set in a glassy to microcrystalline groundmass. They are compositionally similar to orogenic andesites with elevated $\mathrm{TiO}_{2}$ (up to $1.5 \%$ ). The andesites are divisible in two groups that differ in $\mathrm{CaO}, \mathrm{Na}_{2} \mathrm{O}, \mathrm{P}_{2} \mathrm{O}_{5}, \mathrm{Cr}$, and $\mathrm{Sr}$ contents, and in the enrichment of $\mathrm{Ba}$ relative to $\mathrm{Rb}$ and Th. Among the chemically similar andesite samples, those with higher $\mathrm{MgO}$ also contain higher amounts of incompatible elements. Unusually for such rocks, there is no evidence for a significant role of feldspar in the evolution from andesite $\left(61 \% \mathrm{SiO}_{2}\right)$ to dacite $\left(66 \% \mathrm{SiO}_{2}\right)$. A sample from a mafic dyke cutting the Ingalls Head Formation contains high $\mathrm{FeO}(>12 \%$ vs. $\leq 9 \%$ in the host rocks) and $\mathrm{TiO}_{2}(>2 \%)$. The incompatible element pattern of the dyke sample exhibits troughs at $\mathrm{Nb}-\mathrm{Ta}$ and $\mathrm{Sr}$ similar to those shown by the andesite and dacite samples, but not at $\mathrm{Ti}$. The geochemical characteristics of andesite and the time-space-compositional relationship of the dyke with the host andesite are considered to reflect the origin of these rocks by partial melting of hydrous mafic crust under moderate to low pressure $(<8 \mathrm{kbar})$. The melts may have formed in equilibrium with olivine + orthopyroxene + clinopyroxene \pm amphibole \pm plagioclase \pm apatite $\pm \mathrm{Fe}-\mathrm{Ti}$ oxide. Some of the volcanic rocks resemble late Cambrian to late Ordovician rocks of the New River belt on the northwestern margin of the Avalon composite terrane.
\end{abstract}

Le sud-est de l'île Grand Manan est constitué de roches volcaniques d'épanchement et d'explosion des formations de Ross Island et d'Ingalls Head, qui comprennent des sédiments syn-éruptifs et des hyaloclastites. Les laves sont communément amygdaloïdes ou microporphyriques et comportent des phénocristaux de feldspath et, plus rarement, de la pyroxène ou du quartz à l'intérieur d'une matrice rocheuse vitreuse à microcristalline. Les roches ont une composition semblable aux andésites orogéniques avec des teneurs élevées en $\mathrm{TiO}_{2}$ (jusqu'à 1,5\%). On peut subdiviser les andésites en deux groupes dont les teneurs en $\mathrm{CaO}, \mathrm{Na}_{2} \mathrm{O}, \mathrm{P}_{2} \mathrm{O}_{5}, \mathrm{Cr}$, et $\mathrm{Sr}$ et l'enrichissement en $\mathrm{Ba}$ comparativement à celui en $\mathrm{Rb}$ et Th diffèrent. Parmi les échantillons d'andésite qui se ressemblent de près du point de vue chimique, ceux plus riches en $\mathrm{MgO}$ renferment également des quantités supérieures d'éléments incompatibles. Fait exceptionnel dans le cas de magmas de ce genre, on ne relève aucun indice à l'effet que le feldspath aurait joué un rôle déterminant dans l'évolution de l'andésite $\left(61 \%\right.$ de $\left.\mathrm{SiO}_{2}\right)$ au dacite $\left(66 \%\right.$ de $\left.\mathrm{SiO}_{2}\right)$. Un échantillon provenant d'un dyke mafique recoupant la Formation d'Ingalls Head renferme une proportion élevée de $\mathrm{FeO}\left(>12 \%\right.$ par opposition à $\leq 9 \%$ dans les roches hôtes) et de $\mathrm{TiO}_{2}(>2 \%)$. La configuration en éléments incompatibles de l'échantillon de dyke présente des creux face au $\mathrm{Nb}-\mathrm{Ta}$ et au $\mathrm{Sr}$ à l'instar des échantillons d'andésite et de dacite, mais non par rapport au Ti. Les caractéristiques géochimiques de l'andésite et le rapport de composition temps-distance de l'échantillon de dyke avec l'andésite hôte sont considérés comme des attributs révélateurs de l'origine de ces roches, qui proviennent d'une fusion partielle de la croûte mafique hydrique sous une pression moyenne à faible ( $<8$ kbars). Les laves se sont sans doute formées en équilibre avec de l'olivine + orthopyroxène + clinopyroxène \pm amphibole \pm plagioclase \pm apatite \pm oxyde de Fe-Ti. Quelques-unes des roches volcaniques ressemblent aux roches du Cambrien supérieur à l'Ordovicien supérieur de la ceinture de New River, le long de la marge nord-ouest du terrane composite d'Avalon.

Traduit par la rédaction

\section{INTRODUCTION}

\section{Regional geological setting}

Grand Manan Island lies in the north western part of the Bay of Fundy near the New Brunswick - Maine border (Fig. 1). The southeastern part of the island consists principally of deformed metasedimentary and metavolcanic rocks (Alcock 1948; Stringer and Pajari 1981; McLeod et al. 1993; Fyffe and
Grant 2000). The northwestern part of the island consists of early Jurassic tholeiitic basalt (Trembath 1973; Wade et al. 1996).

In southwestern New Brunswick and southeastern Maine, pre-Silurian rocks are commonly obscured by thick sedimentary and volcanic rocks of the Silurian - early Devonian Mascarene Group. The Avalon composite terrane in southern New Brunswick has been divided into the Caledonia and Brookville terranes (Barr and White 1998). The Caledonia 


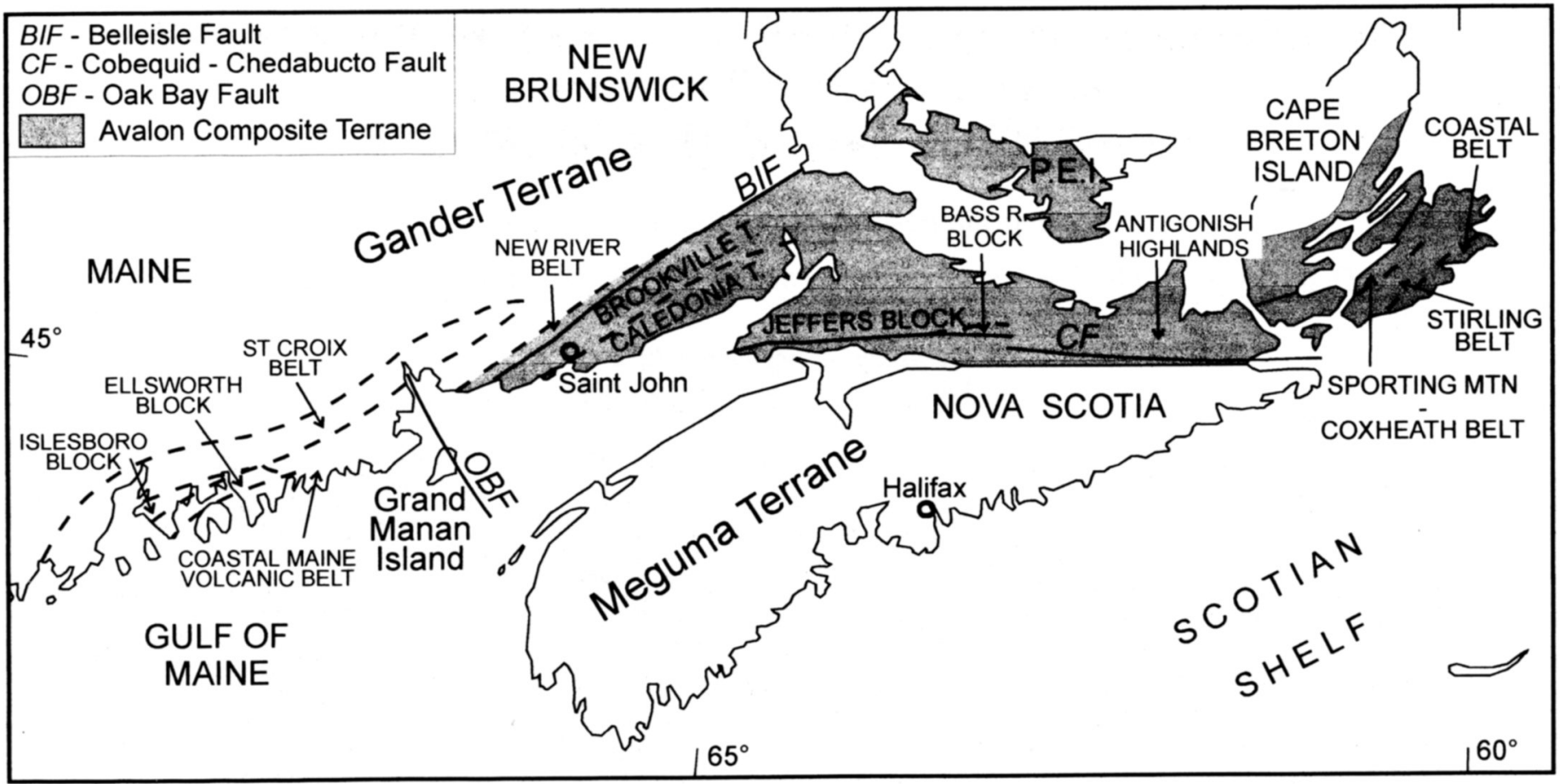

Fig. 1. Regional setting of Grand Manan Island in relation to the Avalon composite terrane.

terrane consists of a collage of late Neoproterozoic arc-related volcanic and plutonic rocks (Barr and White 1988) overlain by a thick succession of shelf sediments of Cambrian age (Tanoli and Pickerill 1988). The Brookville terrane consists of Proterozoic gneiss and platformal metasedimentary and minor volcanic rocks, intruded by late Neoproterozoic to Cambrian plutons. The Islesboro and Ellsworth blocks of southeastern Maine have been correlated, respectively, with the Neoproterozoic and Cambrian of the Brookville and Caledonia terranes (Zen 1983; Rankin et al. 1989). Strongly deformed lower Paleozoic sedimentary and volcanic rocks occur to the north of the Avalon terrane, in the Cookson Group of the St. Croix belt (Ludman 1987; Fyffe et al. 1988) and along the northern margin of the Avalon composite terrane in the New River belt (Johnson and MacLeod 1996).

Correlation of the older rocks of Grand Manan Island with rocks on the mainland has been the subject of considerable debate in the literature. Grand Manan Island lies along strike from the Avalonian composite terrane of southern New Brunswick and consequently the metavolcanic rocks were correlated with the Neoproterozoic volcanic rocks of the Avalon terrane by early workers (Alcock 1948). The rocks also lie along strike from the Coastal Maine blocks (Rankin et al. 1989), overlain by the Mascarene cover sequence (Coastal Volcanic belt of Maine), including probable Cambrian sedimentary and volcanic rocks in the Ellsworth block that may correlate with Cambrian volcanic rocks in southeastern New Brunswick (Greenough et al. 1985) or with the Late Cambrian Mosquito Lake Road volcanics of the New River belt (Johnson and MacLeod 1996; Fyffe and Grant 2000; L.R. Fyffe, personal communication, 2000). These subductionrelated volcanic rocks lie on the northwestern flank of the Avalon composite terrane. Alternatively, Keppie (in Keen et al. 1991) suggested that rocks on Grand Manan Island might be part of the Meguma terrane.

\section{Geology of Grand Manan Island}

In approximate order of age, the following pre-Mesozoic stratified rock units are recognised on Grand Manan Island (Stringer and Pajari 1981; Fyffe and Grant 2000):

1. Black pelite and quartzite are exposed in several of the islands southeast of Grand Manan Island. These sedimentary rocks were termed the Grand Manan Group by Fyffe and Grant (2000) and consist of the Great Duck Island, Flagg Cove, and Thoroughfare formations. Bioturbation structures in the Flagg Cove Formation suggest a Paleozoic rather than Precambrian age for the Grand Manan Group (Fyffe and Grant 2000).

2. The Ross Island unit of McLeod et al. (1993) consists of volcanic flows, hyaloclastite and volcaniclastic sandstone and siltstone. Fyffe and Grant (2000) recognised two formations in the unit: the Ross Island Formation, which is principally mafic flows with minor volcaniclastic sandstone, and the Ingalls Head Formation, which is principally andesitic to dacitic tuff and felsic breccia with purplish sandstone and mudstone. The Ingalls Head Formation has been mapped as conformably or disconformably overlying the Flagg Cove Formation on Long Island (Fyffe and Grant 2000), implying a Paleozoic age for the Ingalls Head Formation. This formation is nowhere in contact with the Ross Island Formation, but Stringer and Pajari (1981) pointed out that both have similar interbedded conglomerate suggesting that they are coeval. The Ingalls Head Formation includes interbedded iron formation, a lithology that is common in Cambrian Avalonian sequences, and Fyffe and Grant (2000) assigned these formations to the Cambrian Ellsworth Group, proposing correlation with the Ellsworth block of southeastern Maine.

3. The Priest Cove Formation, which outcrops on the east coast of Grand Manan Island between Priest Cove and the 
Dock, consists principally of mafic tuff and volcaniclastic sandstone. Moore et al. (1992) identified Paleozoic (tentatively Ordovician, but possibly younger) shallow marine fossils in the sandstone (Hilyard 1992). Although Moore et al. (1992) suggested that metavolcanic rocks of the Ross Island unit unconformably overlie the Priest Cove Formation (metasedimentary rocks), both McLeod et al. (1993) and Fyffe and Grant (2000) regarded the contacts as faulted. The Long Pond Bay Formation outcrops near Red Point and on the Wood Islands to the south and consists of mafic and minor felsic volcanic rocks interbedded with sandstone and mudstone. Fyffe and Grant (2000) assigned both of these formations to the Silurian Mascarene Group.

4. Rocks at North Head (Ruitenberg and McCutcheon 1983) consist of mafic volcanic rocks intruded by gabbro. These volcanic rocks appear to have different $\mathrm{Nd}$ isotope systematics compared with the metavolcanic rocks of the Ross Island unit (Hodgins and Moore 1994) and were correlated with the Silurian Mascarene Group by Ruitenberg and McCutcheon (1983). Fyffe and Grant (2000), however, interpreted the volcanic rocks as part of their Cambrian Ellsworth Group, although they recognised that a Silurian age is possible (L.R. Fyffe, personal communication, 2000).

\section{Purpose of this study}

The volcanic rocks of the Ross Island and Ingalls Head formations are the focus of this study. We describe the petrography and geochemistry of these igneous rocks in order to evaluate possible regional correlations and to contribute to the understanding of the petrogenesis of orogenic andesites.

\section{Materials and methods}

Sample locations are shown in Fig. 2. The volcanic samples 17, 19 and 20 (Table 1) were collected from the Ingalls Head Formation at the type locality and sample 18 was taken from a late dyke that cuts across the felsic volcanic rocks. The remaining volcanic samples $(26,29$ to 35$)$ were obtained from the Ross Island Formation at two localities on the coast of White Head Island (Fig. 2). Three sedimentary rock samples were collected and analysed to evaluate the suggestion (Keen et al. 1991) that the Grand Manan Group might resemble the Meguma Group. Two samples are from turbidite slate (10) and siltstone (11) from the Flagg Cove Formation near The Dock and one sample (I6) is a siltstone from Red Point, mapped as part of the Long Pond Bay Formation by Fyffe and Grant (2000) (Fig. 2).

Geochemical analyses (Table 1) were done by X-ray fluorescence. Rare-earth elements (REE) and selected trace elements were determined by instrumental neutron activation analysis. Procedures and precision are summarized by $\mathrm{Pe}-$ Piper and Piper (1989).

\section{Field ObSERVATIONS}

The volcanic facies of the Ross Island Formation consists of flows (some pillowed), hyaloclastite, breccia and tuff, interbedded with chert, shale and syn-eruptive volcaniclastic sedimentary rocks. McLeod et al. (1993) also reported interbedded limestone. The rocks are all cleaved. Many of the volcanic rocks are amygdaloidal and in places are cut by more massive dykes. Hyaloclastite contains a wide range of decimetre-sized blocks in a cleaved matrix. Both epidote and quartz veins cut the succession. The Ingalls Head Formation consists of grey to purple tuff, minor andesite to dacite flows, and grey to purple mudstone and sandstone.

The sedimentary rocks of the Grand Manan Group include polymictic conglomerate, quartz arenite, lithic arenite, and black carbonaceous shale. McLeod et al. (1993) also reported minor mafic tuff. The rocks show at least two facies associations: sand/shale turbidite and sandstone-conglomerate associations. The turbidite-facies association consist of interbedded quartzose sandstone, siltstone and black shale, with sharp contacts. The proportion of sandstone varies from $15 \%$ to $50 \%$ and the thinner sandstone beds show a more distal aspect, with ripple cross-laminated and some convolute structures. Fine burrows and bioturbation are clearly visible in some silty beds. Pyrite is abundant in some black shale. The sandstone-conglomerate-facies association consists of volcaniclastic sandstone and shale with minor conglomerate beds and appears to be a proximal facies of the turbidite-facies association. These sedimentary rocks differ from early Paleozoic Avalonian cover sequences (e.g. Landing 1996) in the sparsity of fossils and the presence of turbidites, but the bioturbation in the turbidites supports a post-Proterozoic age.

\section{Petrography}

Volcanic rocks of the Ross Island Formation range from basalt to andesite in composition. Most of the samples are amygdaloidal and microporphyritic with glassy to microcrystalline groundmass. Phenocryst abundance does not exceed $5 \%$ in any of the samples studied. Sample 26, one of the two more mafic samples (with $7 \% \mathrm{MgO}$, Table 1), has a felty groundmass defined by randomly oriented feldspar microlites and laths and some epidote, phenocrysts of ferromagnesian minerals (pyroxene?) now represented by brownish crystals with granular outline and vugs filled with chlorite. The other mafic sample, 30 , is a hyaloclastite composed of angular, formerly glassy, fragments, devitrified to microlite around coarse vesicles. The vesicles are filled with chlorite, quartz and epidote. Chlorite and epidote also occur as replacement minerals, possibly after plagioclase and ferromagnesian minerals.

Intermediate volcanic rocks (3-5\% $\mathrm{MgO}$, Table 1) of the Ross Island Formation (samples 29,32 to 35 ) mostly consist of devitrified groundmass with microphenocrysts of zoned, feldspar laths that in places form glomerophenocrysts, and rarely amphibole or quartz. Sample 33 has perlitic texture and is entirely altered to epidote and chlorite. It also contains a stockwork of veinlets of quartz. Sample 34 is also pervasively epidotised and chloritised, and hosts well developed syntaxial quartz veins as in sample 33, indicating a close association between the development of quartz veins and epidotisation.

In the Ingalls Head Formation, intermediate sample 17 is petrographically similar to intermediate samples from the Ross Island Formation. The felsic samples 19 and 20 have alkali and plagioclase feldspar phenocrysts in a dusty groundmass of feldspar, chlorite, opaque minerals and quartz. Epidote and quartz veins are present, as well as chlorite-epidote-quartz 


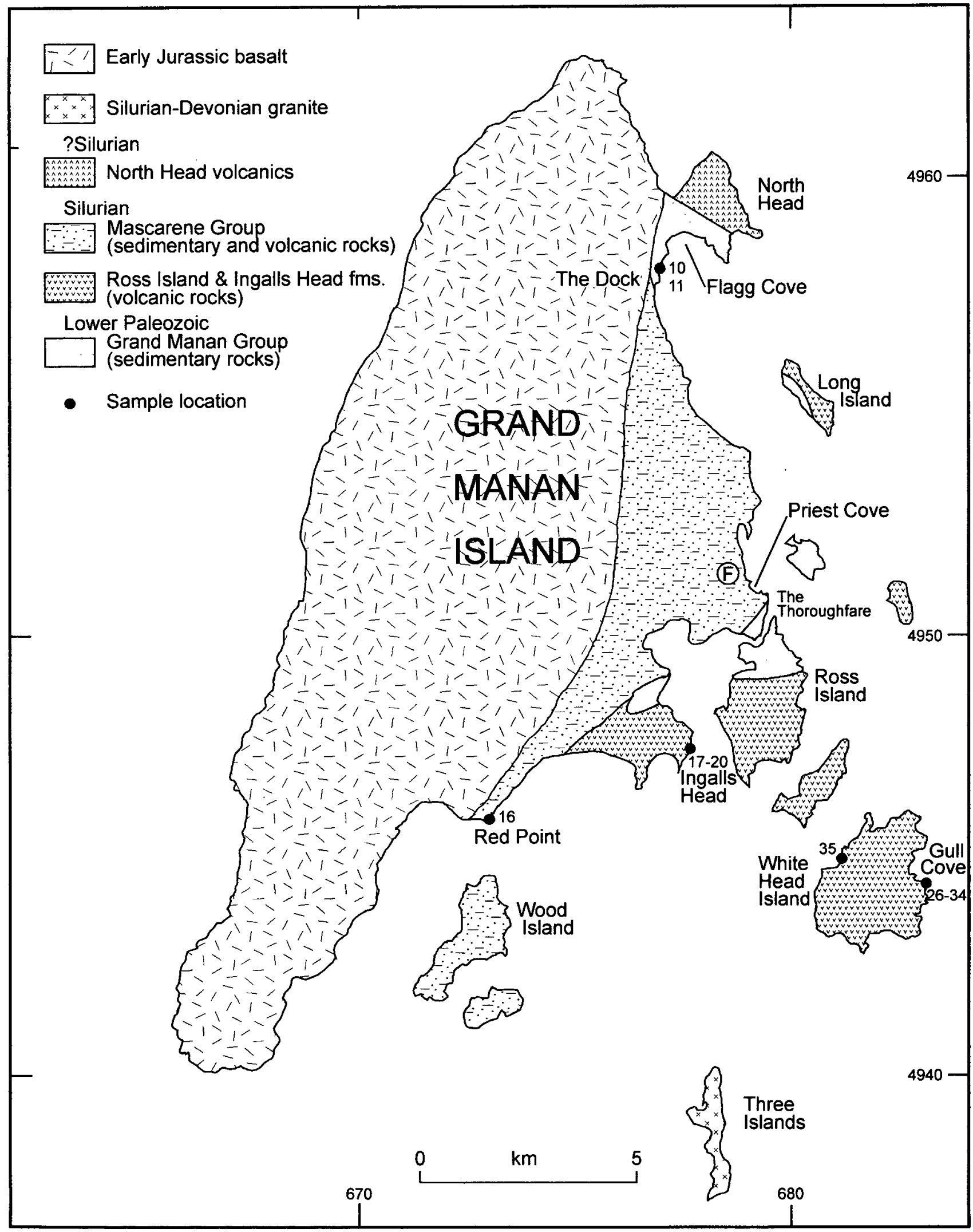

Fig. 2. Geological map of Grand Manan Island (from Alcock 1948; Stringer and Pajari 1981; McLeod et al. 1993; Fyffe and Grant 2000). 
Table 1: Representative chemical analyses of igneous lithologies

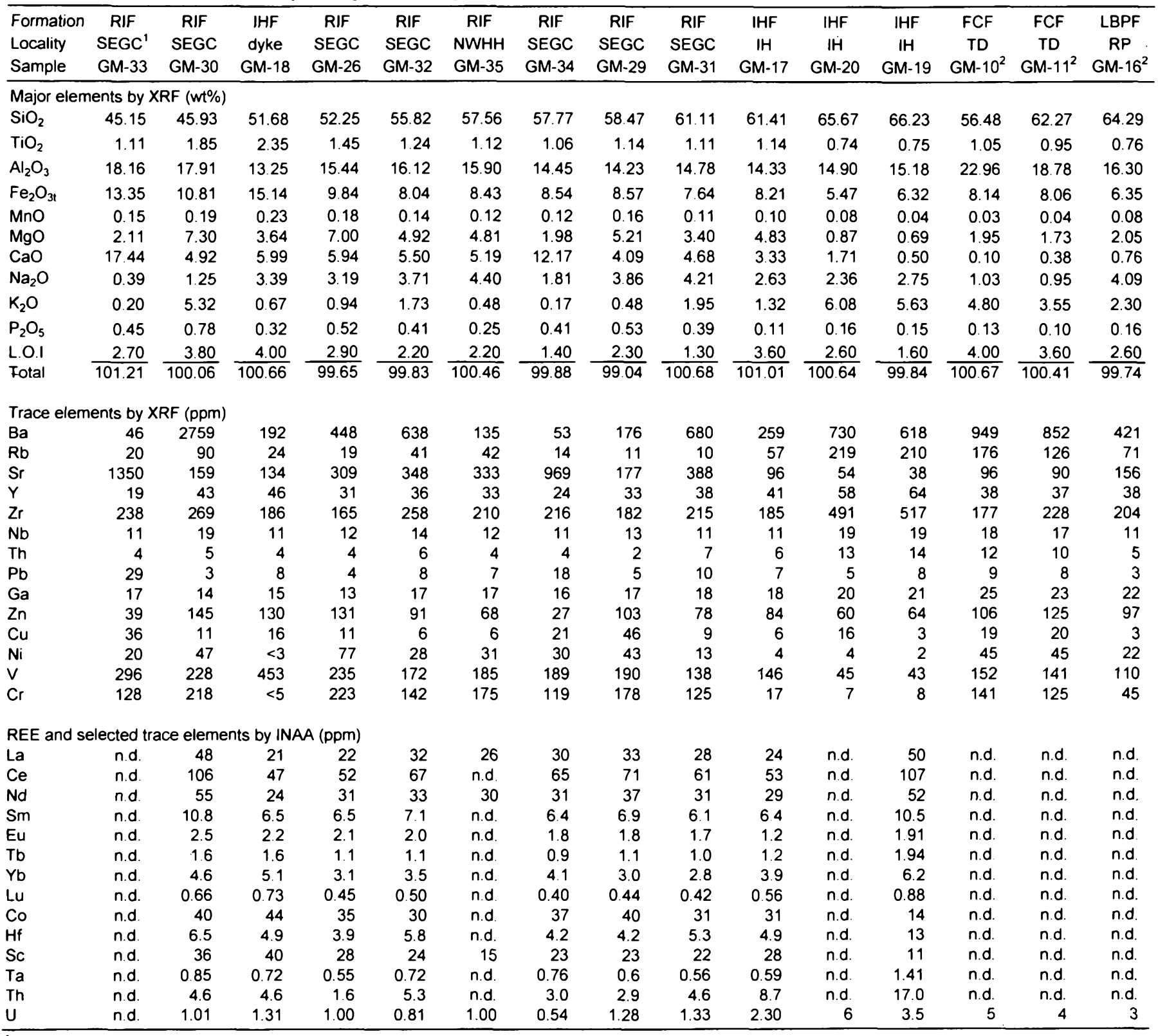

'RIF: Ross Island Formation; IHF: Ingalls Head Formation; FCF: Flagg Cove Formation; LBPF: Long Bay Pond Formation. SEGC: southern end of Gull Cove; IH: Ingalls Head; NWHH: north of White Head Harbour; TD: The Dock; RP: Red Point

${ }^{2}$ Sedimentary rocks

replacements. Sample 18, taken from a mafic dyke that cuts the felsic volcanic rocks, is aphyric with plagioclase laths and interstitial quartz. Chlorite and epidote have replaced original crystals with crystal shapes suggesting clinopyroxene. Opaque minerals are abundant and include subhedral magnetite and euhedral to anhedral pyrite and equant chalcopyrite crystals.

Sedimentary rocks of the Flagg Cove Formation (samples 10 and 11) are strongly cleaved, and contain very fine grained sand- to silt-size grains of quartz in a predominantly sericitic matrix. Sample 16 from the Long Pond Bay Formation displays clastic texture with abundant fine-grained, angular to subrounded quartz grains and a small amount of feldspar set in a sericitic matrix.

\section{GeOCHEMISTRY}

Both field and petrographic observations indicate that the igneous rocks have undergone variable degrees of alteration. For this reason immobile elements were used to classify the rocks and detailed investigations of the major and trace elements were carried out to distinguish between alteration and primary compositional features. The following discussion is based on hydrous compositions of the rocks (Table 1). The anhydrous compositions are plotted in Figs. 3 to 5 .

On the $\mathrm{Zr} / \mathrm{TiO}_{2}$ vs. $\mathrm{Nb} / \mathrm{Y}$ discrimination diagram (Winchester and Floyd 1977; Fig. 3) samples from the Ross Island Formation plot principally as andesite, with rare basalt, whereas samples from the Ingalls Head Formation plot as andesite and dacite, with a basalt dyke. This is consistent with the mineralogical compositions of the rocks, described above, 


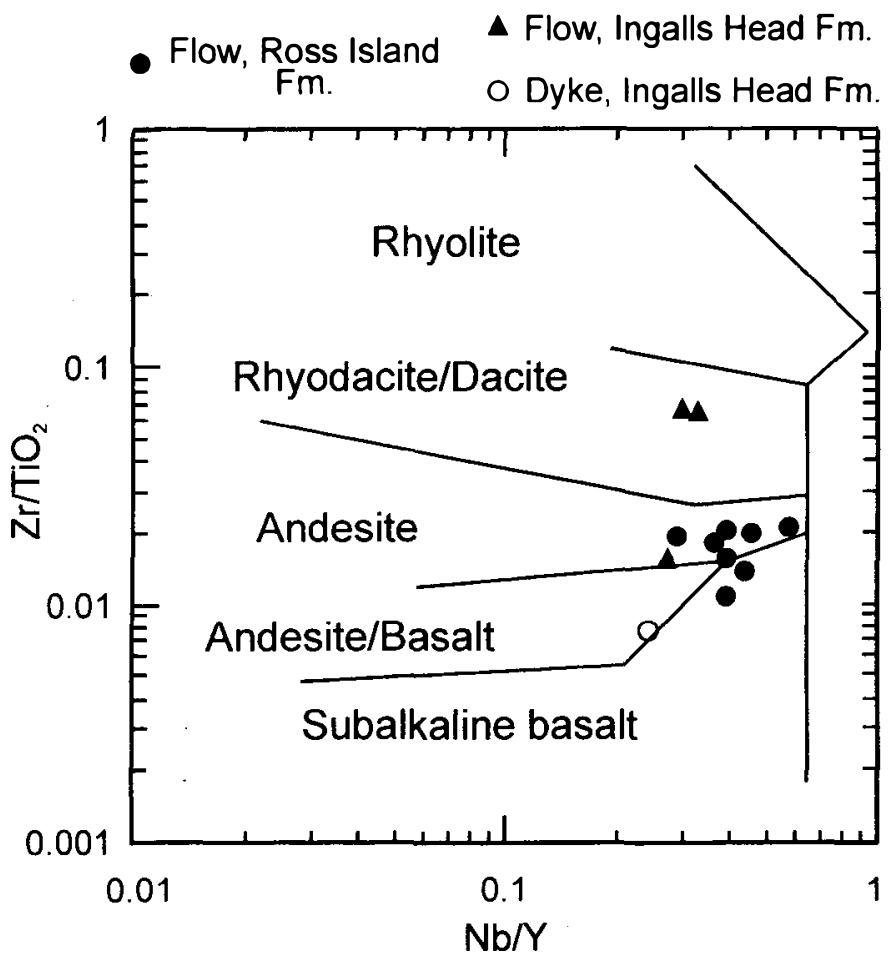

Fig. 3. Plot of $\mathrm{Zr} / \mathrm{TiO}_{2}$ against $\mathrm{Nb} / \mathrm{Y}$. The names of the fields are after Winchester and Floyd (1977).

and their $\mathrm{SiO}_{2}$ contents (Table 1, Fig. 4). Most of the samples contain between 52 and $62 \% \mathrm{SiO}_{2}$; two samples from the Ingalls Head Formation $\left(19,20\right.$ ) contain $\sim 66 \% \mathrm{SiO}_{2}$ (Table 1), and two samples from the Ross Island Formation $(30,33)$ contain $<52 \% \mathrm{SiO}_{2}$ (Table 1).

The chemical similarity of samples 33 and 34 in terms of $\mathrm{MgO}$ content ( $2 \%$; Table 1; Fig. 4$)$, reflects the effects of epidote and chlorite alteration, clearly observed petrographically. These samples have distinctly low $\mathrm{Na}_{2} \mathrm{O}$ and $\mathrm{K}_{2} \mathrm{O}$ contents and markedly high contents of $\mathrm{FeO}, \mathrm{CaO}, \mathrm{V}$ and Sr (Table 1; Figs. 4 and 5), at low $\mathrm{MgO}$. This type of alteration may be responsible for the decreasing trend in $\mathrm{K}_{2} \mathrm{O}$ with decreasing $\mathrm{MgO}$ (Fig. 4).

Sample 30 has $\mathrm{MgO}$ content similar to that of sample 26, and also has similar $\mathrm{CaO}, \mathrm{Cr}$ and $\mathrm{V}$ contents (Figs. 4 and 5). In this context, the relatively low $\mathrm{SiO}_{2}$ and $\mathrm{Na}_{2} \mathrm{O}$, and the relatively high contents of $\mathrm{TiO}_{2}$ and $\mathrm{Al}_{2} \mathrm{O}_{3}$, of sample 30 might be the consequence of alteration. It should be noted that this sample is a hyaloclastite, and thus likely susceptible to alteration. But it is unlikely that alteration would result in the systematic enrichment of the REE and other incompatible elements in sample 30, relative to sample 26 (Figs 6a and 7a).

Excluding highly altered samples 33 and 34 , the remaining six samples from the Ross Island Formation show regular trends in variation of major and compatible trace elements with $\mathrm{MgO}$, which might be interpreted as resulting from evolution by crystal fractionation. However, the evolved rocks have different REE and incompatible element patterns (Figs. 6 and 7) from the presumed parent rock and from one another, and the difference does not support a crystal fractionation relationship among these rocks. Indeed, the positive relationships between $\mathrm{MgO}$ and incompatible element contents such as observed in the more mafic samples 26 and 30 is also displayed by andesite samples 29,31 and 32 (Table
1; Figs. $6 \mathrm{~b}$ and $7 \mathrm{~b}$ ).

The Ingalls Head andesite sample 17 has $4.8 \% \mathrm{MgO}$ at $61.4 \% \mathrm{SiO}_{2}$. On most of the variation plots, this sample appears to be parental to the Ingalls Head dacite samples (Figs. 4 and 5). But this evolution did not appear to involve feldspar as $\mathrm{Na}_{2} \mathrm{O}$ and $\mathrm{Al}_{2} \mathrm{O}_{3}$ are nearly constant, whereas $\mathrm{K}_{2} \mathrm{O}$ increases dramatically from the presumed andesite parent sample $17\left(\mathrm{~K}_{2} \mathrm{O}=1.32 \%\right)$ to the dacite samples $\left(\mathrm{K}_{2} \mathrm{O}=5\right.$ $6 \%$ ). The REE patterns of the andesite and dacite samples are nearly parallel (Fig. 6c). The magnitude of Eu depletion relative to $\mathrm{Tb}$ and $\mathrm{Sm}$ does not differ significantly between the samples (Fig. 6c). Only Sr shows evidence of significant depletion (Fig. 7c), but this alone cannot be used to suggest a significant involvement of feldspar.

Some compositional differences occur between samples from the Ingalls Head and the Ross Island formations. The former contain relatively low $\mathrm{CaO}, \mathrm{Na}_{2} \mathrm{O}, \mathrm{P}_{2} \mathrm{O}_{5}, \mathrm{Sr}$ and $\mathrm{Cr}$ (Figs. 4 and 5). In addition, systematic variations in $\mathrm{Ba}, \mathrm{K}, \mathrm{Rb}$, and Th are recorded between the two suites of rocks (Fig. 7). The spider plots of the Ross Island Formation samples show variable degree of enrichment of $B a$ relative to $R b$ and $T h$ (Fig. 7a, b), whereas those of the Ingalls Head Formation show relative $\mathrm{Ba}$ depletion (Fig. $7 \mathrm{c}$ ). $\mathrm{Ba} / \mathrm{Rb}$ vs. $\mathrm{K} / \mathrm{Th}$ shows a positive correlation, which suggests that $\mathrm{Ba}$ and $\mathrm{K}$ behave coherently with respect to $\mathrm{Rb}$ and $\mathrm{Th}$ among the Ross Island andesites.

Mafic dyke sample 18 from Ingalls Head Formation differs from the Ross Island Formation samples with similar $\mathrm{MgO}$ contents in having relatively low $\mathrm{SiO}_{2}$ and $\mathrm{Al}_{2} \mathrm{O}_{3}$ and distinctly high $\mathrm{FeO}$ and $\mathrm{TiO}_{2}$ (Fig. 4). It also shows quite a distinct pattern of both REE distribution (Fig. 6c) and of incompatible trace elements (Fig. 7c). However, the distribution of incompatible trace elements and REE is very similar to that in the Ingalls Head Formation andesite sample (17) except that the andesite shows significant fractionation of $\mathrm{P}, \mathrm{Eu}$ and $\mathrm{Ti}$. In particular, the Ingalls Head Formation samples show little relative depletion in $\mathrm{Y}, \mathrm{Yb}$ and $\mathrm{Lu}$ compared with the middle REE, in contrast to the strong depletion in the Ross Island Formation basalt and andesite samples (Fig. 7).

Three analyses of sedimentary rocks from the Grand Manan Group differ substantially from sedimentary rocks of the Meguma Group with similar $\mathrm{SiO}_{2}$ content (compared with the compilation of Stevens et al. 1999, and the data of Feetham et al. 1997). For example, the Grand Manan Group samples have substantially higher $\mathrm{Ni}$ and $\mathrm{Cr}$, rather higher $\mathrm{TiO}_{2}$ and rather lower $\mathrm{MgO}$ and $\mathrm{Sr}$. The high $\mathrm{Cr}, \mathrm{Ni}$ and $\mathrm{V}$ are characteristic of an Avalonian source terrane (cf. Murphy et al. 1996, Goulden 1998). Further interpretation is not justified by the limited amount of data.

\section{PETROGENESIS OF IGNEOUS ROCKS}

The petrogenesis of orogenic andesites (Gill 1981; Hess 1989) remains uncertain. Several major hypotheses for the origin of these rocks have been proposed in the literature, including (1) partial melting of peridotite mantle, (2) partial melting of basaltic eclogite, (3) fractionation of $\mathrm{H}_{2} \mathrm{O}$-poor basalt and (4) partial melting of hydrous mafic lower crust. The direct derivation of andesites by partial melting of 

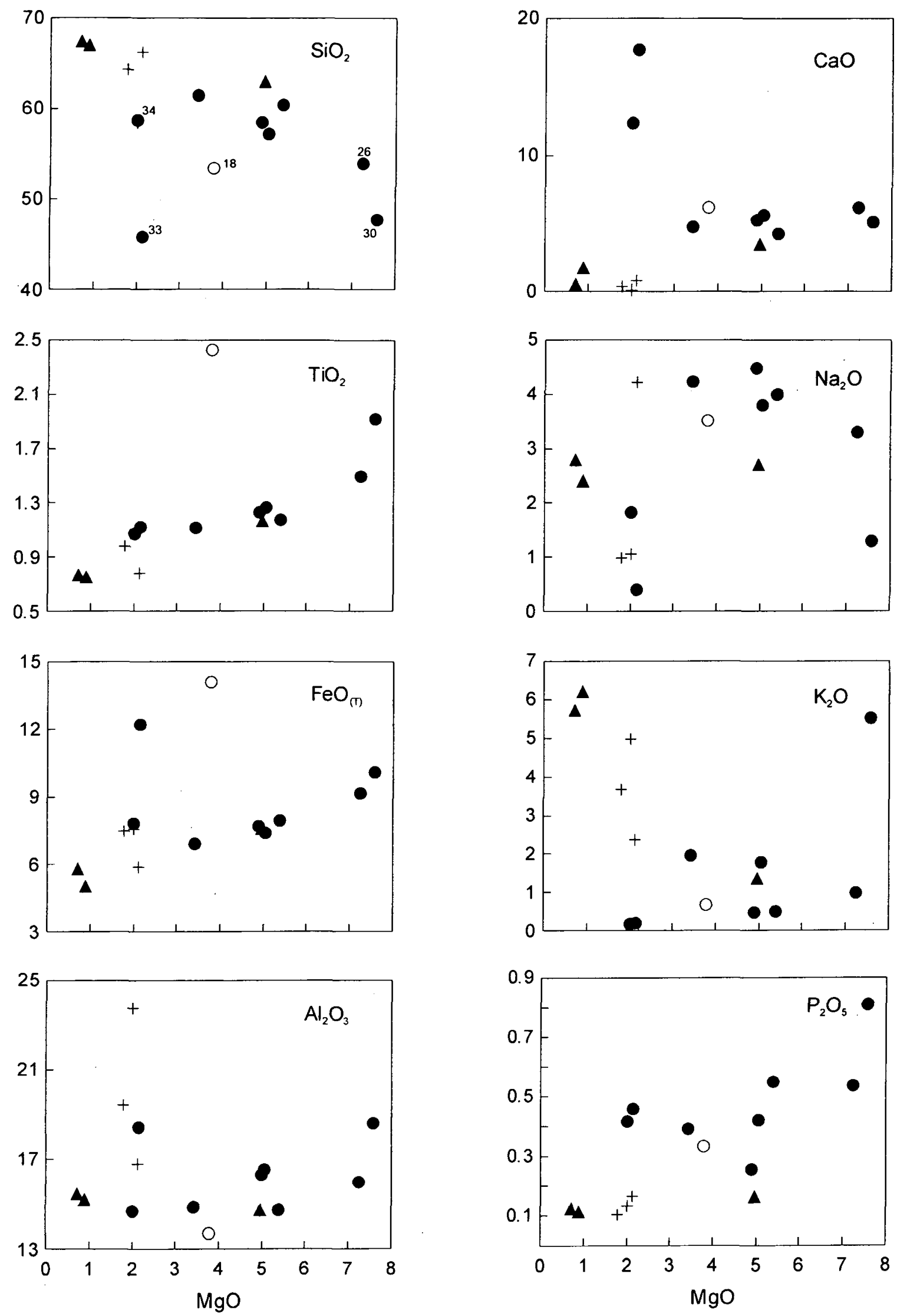

Fig. 4. Plots of major elements against $\mathrm{MgO}$ for analysed volcanic rocks samples from the Ross Island and Ingalls Head formations. Symbols as in Fig. 3. ' + ' = sedimentary rock sample. 

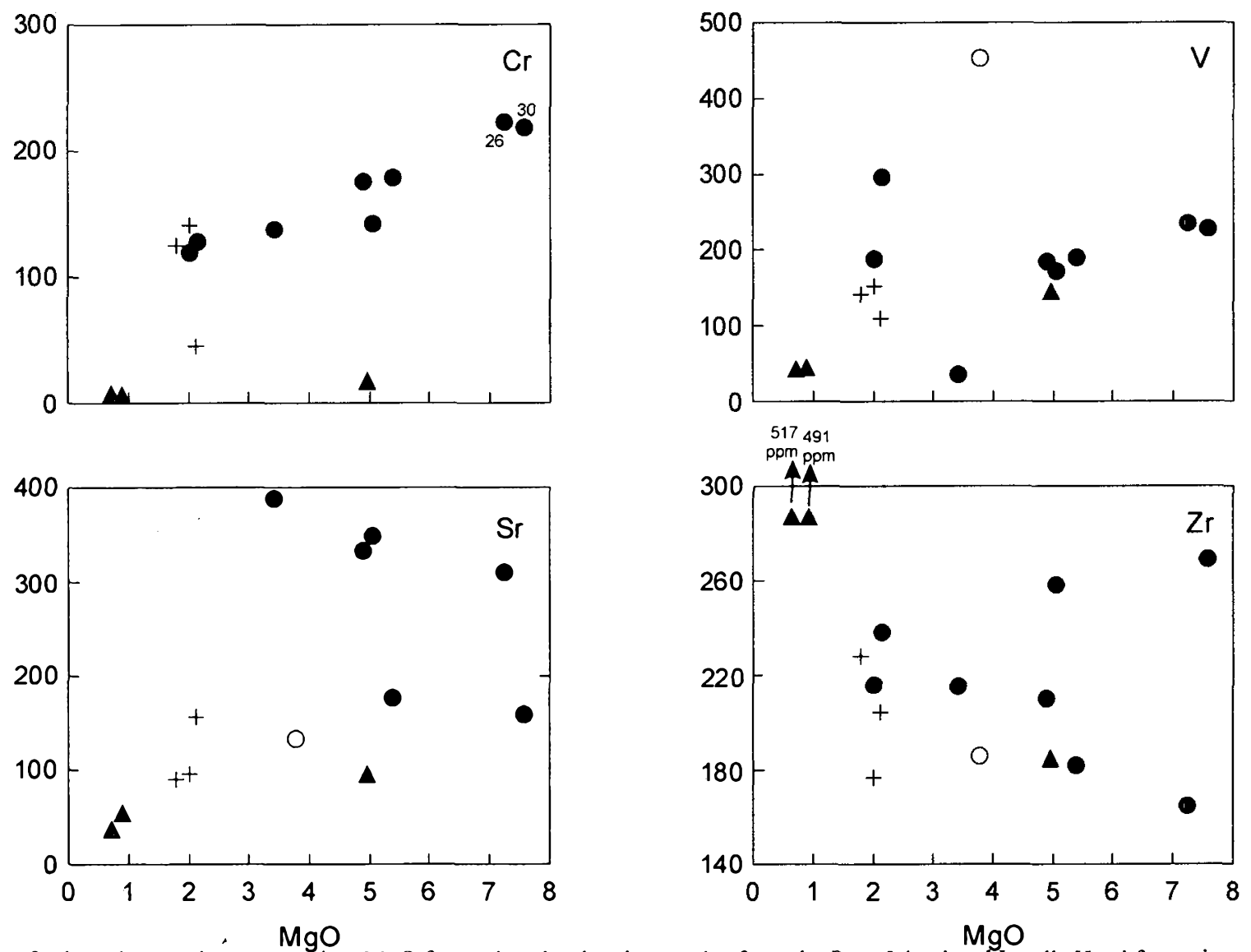

Fig. 5. Plots of selected trace elements against $\mathrm{MgO}$ for analysed volcanic samples from the Ross Island and Ingalls Head formations. Symbols as in Fig. 3.

peridotite mantle (1) is rejected because $\mathrm{Mg}, \mathrm{Ni}$ and $\mathrm{Cr}$ contents are lower than expected of rocks that form in equilibrium with mantle olivine. Significant quantities of garnet must be left in the residue to produce andesitic melts by partial melting of basaltic eclogite (2). The absence of strong fractionation of the light to heavy REE in andesites weakens this suggestion. The major and trace element characteristics of natural andesites are closely reproduced by fractionation of olivine, clinopyroxene, plagioclase and $\mathrm{Fe}-\mathrm{Ti}$ oxide from $\mathrm{H}_{2} \mathrm{O}$ poor basalt at moderate pressures. Supporting the model results are the smooth variations in major elements displayed by suites of orogenic rocks on Harker-type diagrams. Fractional crystallization (3) is thus accepted as a plausible mechanism for deriving andesite from basalt. Alternatively andesite can be derived by partial melting of hydrous mafic crust. This process is invoked when the geochemical characteristics of siliceous volcanic rocks deviate from the common characteristics of rocks derived by fractional crystallization. Below we outline some compositional characteristics of the Ross Island andesite that we interpret to reflect their origin by partial melting of hydrous mafic crust (4).

Our petrographic and geochemical data indicate that the Ross Island Formation andesite samples are generally aphyric rocks composed of $52-62 \% \mathrm{SiO}_{2}, 1-1.5 \% \mathrm{TiO}_{2}, 14-16 \%$ $\mathrm{Al}_{2} \mathrm{O}_{3}, 7.5-10 \% \mathrm{FeO},<6 \% \mathrm{CaO}, 3-7 \% \mathrm{MgO}, \leq 4.5 \% \mathrm{Na}_{2} \mathrm{O}$, $<2 \% \mathrm{~K}_{2} \mathrm{O}$ and $\leq 0.5 \% \mathrm{P}_{2} \mathrm{O}_{5}$. These values are similar to those of orogenic andesites, in particular to those from Fuji volcano
(Honshu) and Slamet volcano (Java), which are also enriched in $\mathrm{TiO}_{2}$ (Gill 1981). The troughs at $\mathrm{Nb}-\mathrm{Ta}$ and $\mathrm{Ti}$ shown by the incompatible element patterns of the Ross Island Formation andesite samples (Fig. 7) are also characteristic features of arc-related volcanic rocks. The rocks contain $<400$ ppm $\mathrm{Sr}$ and exhibit negative Eu anomaly (Fig. 6b) and systematic variations in $\mathrm{Ba}, \mathrm{K}, \mathrm{Rb}$ and $\mathrm{Th}$.

The aphyric nature of the Ross Island Formation andesite samples contrasts with the usual phenocryst-laden nature of orogenic andesites (Hess 1989). Given this, the consistent positive correlation between $\mathrm{MgO}$ and incompatible element abundances among chemically similar rocks could not be the result of either fractional crystallization or occasional crystal accumulation, or of mixing between highly evolved and mafic magmas. Furthermore, the relationship between $\mathrm{MgO}$ and incompatible element abundances among the Ross Island Formation andesite samples is opposite to that postulated for adakite genesis. In the latter case, mixing of slab-derived silicic melts with mantle peridotite and/or basalt is perceived to impart primitive character to the melts (increases $\mathrm{MgO}, \mathrm{Ni}$, $\mathrm{Cr}$ ), to lower the concentrations of incompatible elements, and to dampen most of the inter-element fractionation produced by eclogite melting (Yogodzinski et al. 1996; Stern and Kilian 1996). This process results in increasing incompatible element abundance with decreasing $\mathrm{MgO}$, in a way analogous to crystal fractionation.

Derivation of the Ross Island Formation andesite by partial melting is also indicated by the absence of significant 

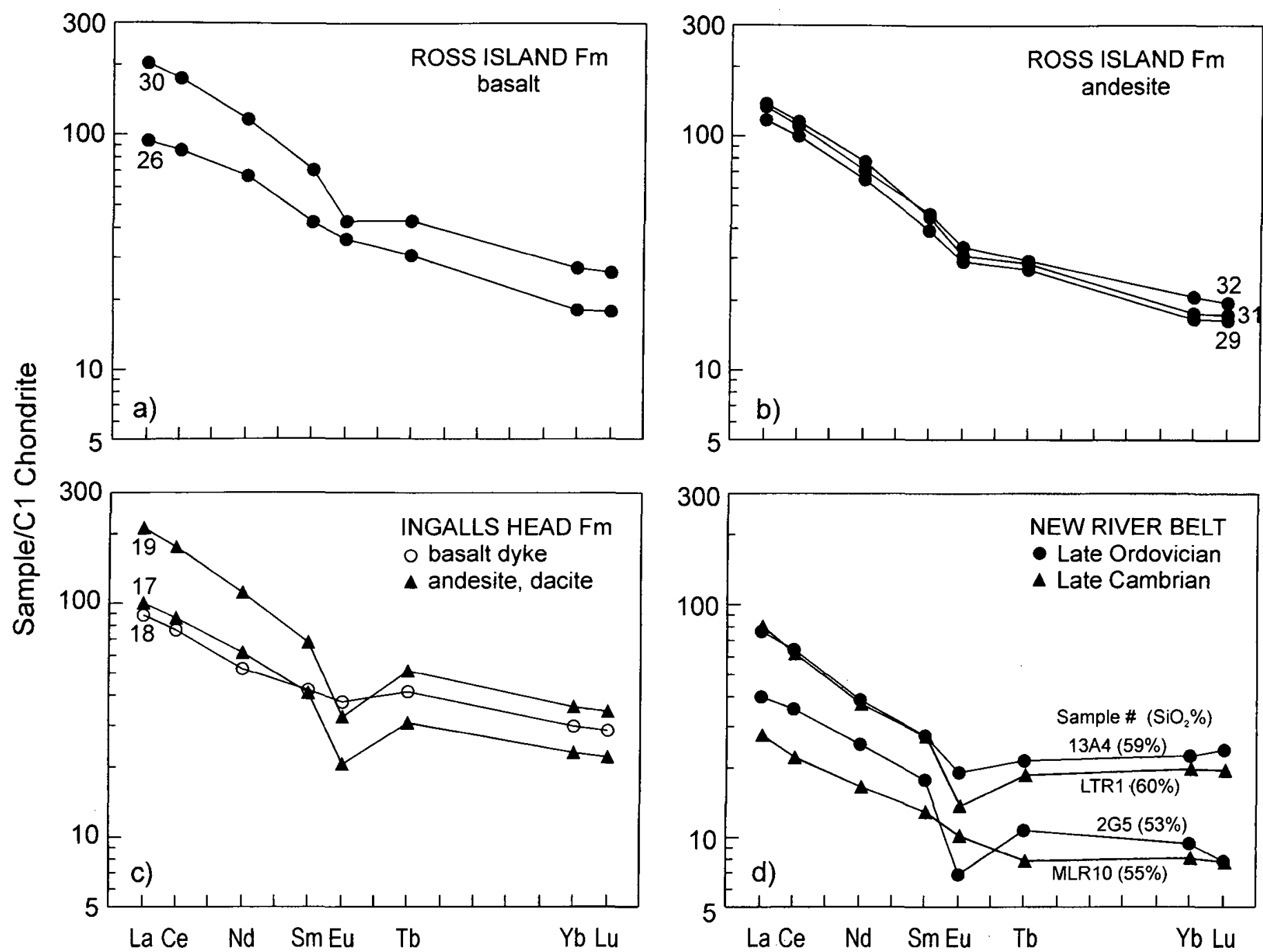

Fig. 6. Chondrite-normalized rare-earth-element abundances in representative samples. (a) Ross Island Formation basalt; (b) Ross Island Formation andesite; (c) Ingalls Head Formation; (d) New River belt (data from Johnson and McLeod 1996). Symbols as in Fig. 3.

feldspar involvement during the andesite-dacite transition. If the Ingalls Head Formation andesite and dacite samples are presumed to be related by fractional crystallization, the apparent interruption in feldspar crystallization would be a rather unusual process for such types of magmas. Petrographic observations and the negative Eu anomaly in the REE patterns indicate the involvement of plagioclase at some stage. It is possible that an increase in $\mathrm{a}_{\mathrm{H}_{2} \mathrm{O}}$ in the evolved andesite magma might have prohibited the further crystallization of feldspar (Rushmer 1993), although no hydrous phases reflecting this increase were observed petrographically. It may be, therefore, that the dacite was produced by partial melting of a hydrous source.

Furthermore, differences in major element contents between the andesites of the Ingalls Head and Ross Island formations appear to be coupled to differences in trace elements, which together can be explained by assuming the origin of these rocks by partial melting of a mafic crust. The relatively low $\mathrm{CaO}, \mathrm{Na}_{2} \mathrm{O}, \mathrm{P}_{2} \mathrm{O}_{5}, \mathrm{Cr}, \mathrm{Sr}, \mathrm{Ba} / \mathrm{Rb}$ and $\mathrm{K} / \mathrm{Th}$ of the Ingalls Head Formation andesite samples indicate that pyroxene, plagioclase and apatite are residual in their source. Variable enrichment of $\mathrm{Ba}$ relative to $\mathrm{Rb}$ and $\mathrm{Th}$ of the type displayed by the Ross Island Formation andesite samples is also observed in adakites from the Austral Volcanic Zone of the Andes (Stern and Kilian 1996; Wilson 1989). K/Rb and $\mathrm{K} / \mathrm{Ba}$ values, respectively, range from $500-600$ and $15-20$ in the Ross Island Formation andesite samples, to as low as 200 and 40 in the Ingalls Head Formation andesite. The range of $\mathrm{K} / \mathrm{Rb}$ ratios corresponds with that in tonalite-trondhjemitedacite suites $(\geq 600)$ to that of the crustal average (Drummond and Defant 1990; Taylor and McLennan 1985), indicating that the $\mathrm{K}, \mathrm{Ba}$, and $\mathrm{Rb}$ systematics are not an artefact of weathering. Several recent studies on mantle xenoliths indicate that the depletion of $\mathrm{Ba}$ relative to $\mathrm{Rb}$ and $\mathrm{Th}$ is characteristic of sources dominated by pyroxene, whereas the converse is true of amphibole-dominated sources (e.g., ChalotPrat et al. 1997).

Thus, the andesite appears to have been derived by partial melting of hydrous mafic crust under moderate to low pressure $(<8 \mathrm{kbar})$. The more mafic andesite samples of the Ross Island Formation may have formed in a residue containing olivine + orthopyroxene + clinopyroxene + amphibole \pm plagioclase \pm $\mathrm{Fe}-\mathrm{Ti}$ oxide. Andesite of the Ingalls Head Formation seems to have equilibrated with a similar residue but dominated by 

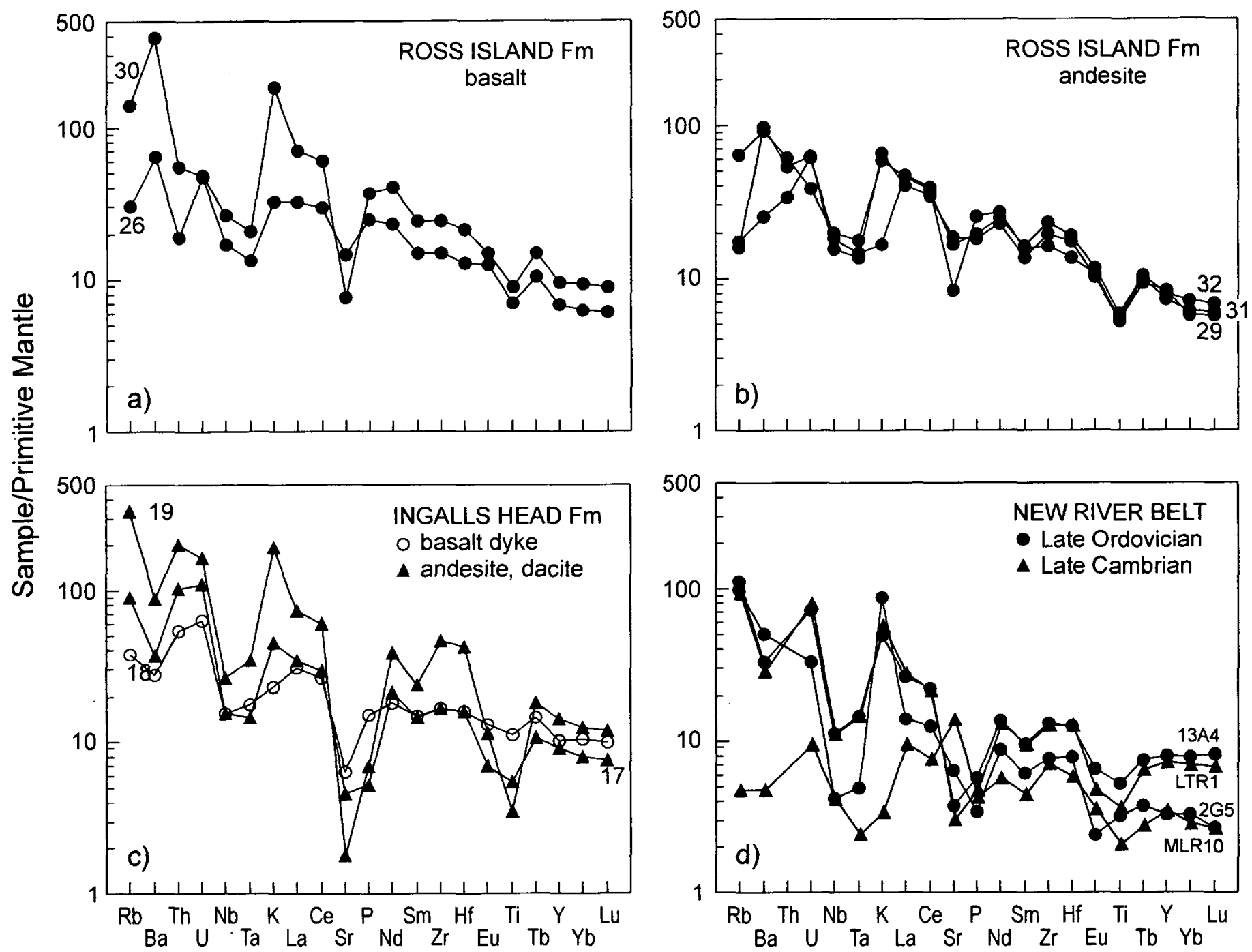

Fig. 7. Element variation plots for selected samples. (a) Ross Island Formation basalt; (b) Ross Island Formation andesite; (c) Ingalls Head Formation; (d) New River belt (data from Johnson and McLeod 1996). Symbols as in Fig. 3. Samples normalized to primitive mantle (from Sun and McDonough 1989). Samples as in Fig. 6.

pyroxene.

In several models of crustal melting, basaltic magmas are considered to supply the heat required for inducing partial melting of underplated crust. The inferred process for the Grand Manan Island units is that hot basaltic magmas intruded to shallow levels. The andesite and, in particular, the dacite may have been produced by water-undersaturated melting, as melting experiments at moderate to low pressures produce distinctly less mafic melts in water-undersaturated conditions versus water-saturated conditions (Beard and Lofgren 1991; Rapp and Watson 1995).

Dyke sample 18 bears a striking similarity in incompatible element patterns to the associated andesite of the Ingalls Head Formation (Fig. 7c), but contains higher $\mathrm{FeO}$ and $\mathrm{TiO}_{2}$ (Fig. 7). These relations raise the possibility that this rock might have been produced by partial melting of a similar mafic crust as that of the source of the andesite but under reducing conditions. This implies that $\mathrm{Fe}$-Ti-bearing oxide phases were residual in the source of the andesites. In this scenario, the elevated $\mathrm{TiO}_{2}$ contents of the Ross Island Formation andesite, and the relatively small variation in $\mathrm{FeO}$ and $\mathrm{TiO}_{2}$ compared to $\mathrm{SiO}_{2}$ (Fig. 4) would reflect buffering of these elements.

\section{REGIONAL CORRELATIONS}

The general assemblage of flows and pyroclastic rocks of andesitic and dacitic composition is common in the late Neoproterozoic of the Avalon composite terrane (Fig. 1), as summarized by Barr (1993) for southern Cape Breton Island, Murphy et al. (1990) for the Antigonish Highlands, Pe-Piper and Piper (1989) for the Cobequid Highlands and Barr and White (1988) for southern New Brunswick. Geochemical differences between flows in different parts of the Avalon terrane are subtle and precise correlations with the Grand Manan Island volcanic rocks are not apparent. For example, the Grand Manan Island mafic rocks have relatively high $\mathrm{Zr}$ content relative to $\mathrm{Y}$ and $\mathrm{TiO}_{2}$ (Fig. 8c); this feature is characteristic of the Coxheath-Sporting Mountain and Stirling belts of southern Cape Breton island, but both of these belts consist mostly of either basalt or rhyolite, with less andesite 
a)

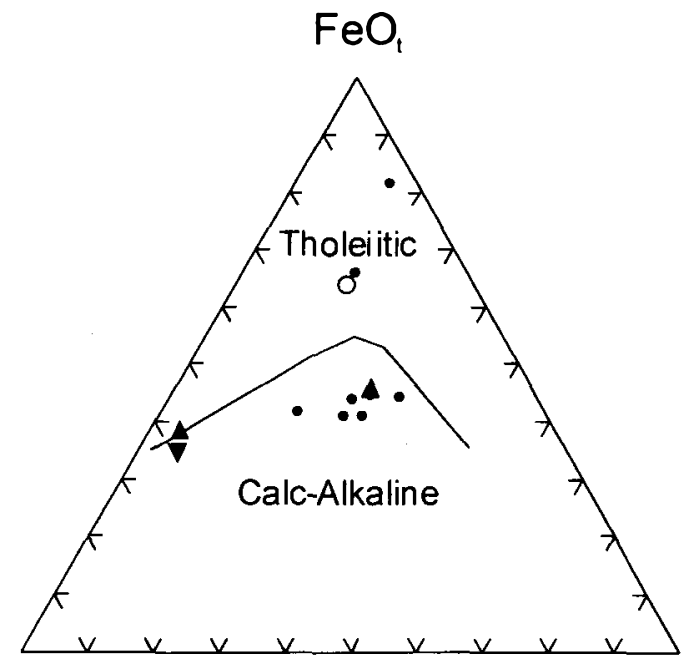

$\mathrm{Na}_{2} \mathrm{O}+\mathrm{K}_{2} \mathrm{O}$

c)

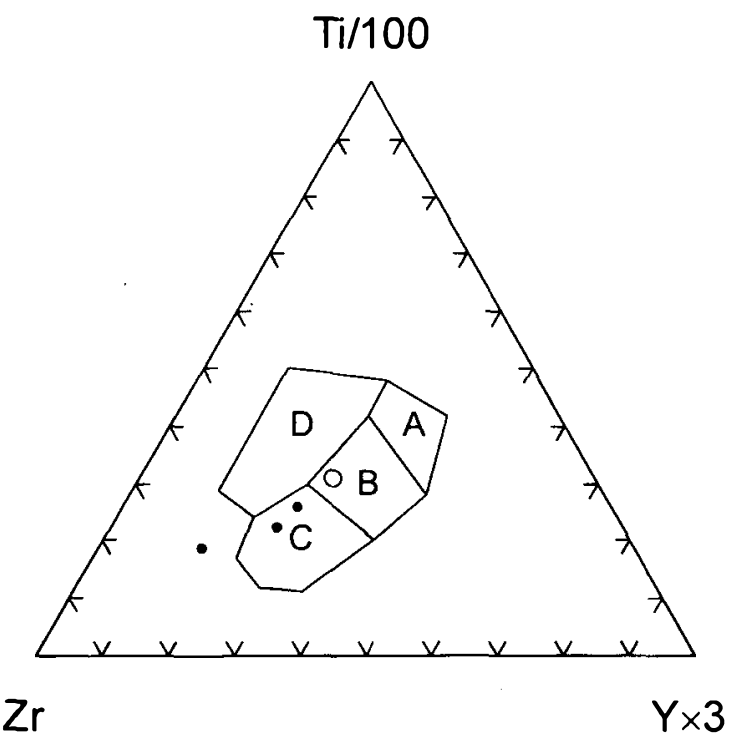

b)

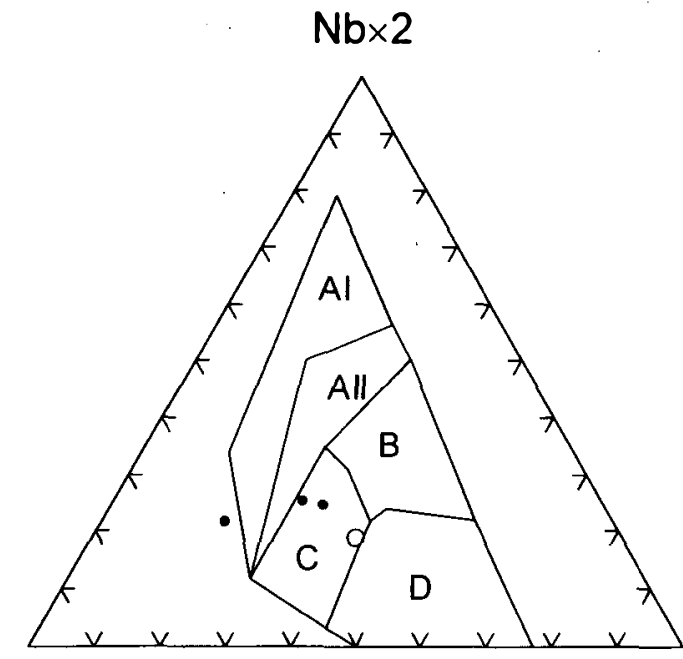

$\mathrm{Zr} / 4$

d)

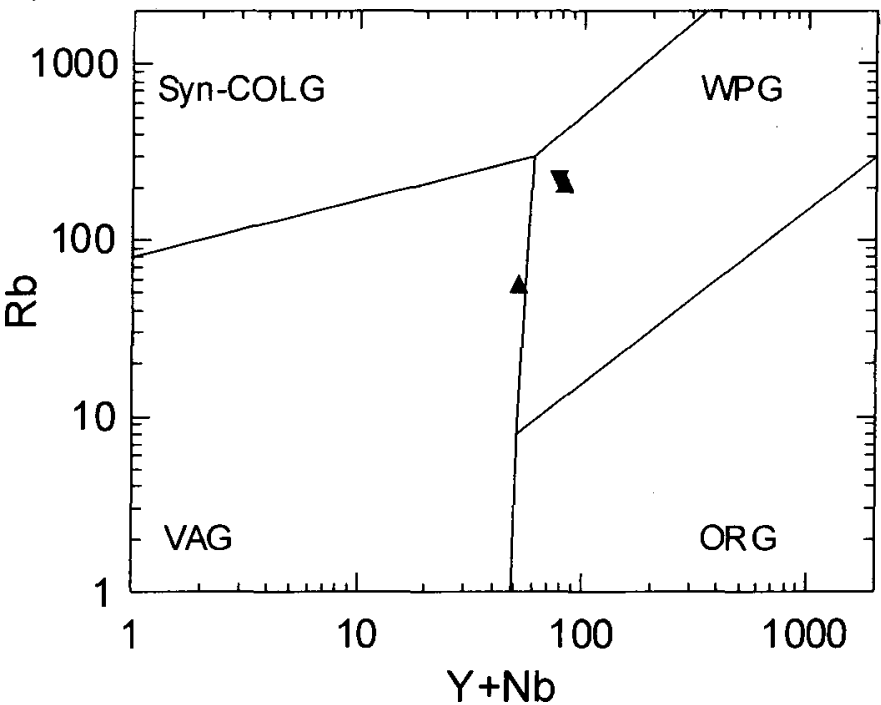

Fig. 8. Selected multi-element plots for volcanic samples from the Ross Island and Ingalls Head formations. Symbols as in Fig. 3. These plots allow ready comparison with the various Avalonian belts of southern Cape Breton Island presented by Barr (1993) and with the New River belt presented by Johnson and McLeod (1996). (a) from Irvine and Baragar (197I); (b) for mafic rocks, from Meschede (1986); (c) for mafic rocks, from Pearce and Cann (1973); (d) for felsic rocks, from Pearce et al. (1984).

and dacite than on Grand Manan Island (Fig. 1). Furthermore, the field evidence that the Ingalls Head Formation overlies the bioturbated Flagg Cove unit implies an age younger than Neoproterozoic. The Grand Manan Island volcanic rocks are also geochemically quite distinct from Early to Middle Cambrian volcanic rocks of the New River belt, which are principally continental tholeiites (Greenough et al. 1985).

Many authors have suggested correlations with the northern margin of the Avalon composite terrane or the southern part of the Gander terrane, notably the Cookson Group of the Saint Croix terrane (Stringer and Pajari 1981) (Fig. 1). The Grand Manan Island samples of this study are quite different from the tholeiitic basalt and minor rhyolite of the Cookson Group (Fyffe et al. 1988) and correlative rocks of the Annidale Group (McLeod et al. 1994). A closer geochemical resemblance is found between the rocks of this study and volcanic rocks of the New River belt (Johnson and McLeod 1996). In the southwestern part of the belt, intermediate volcanic rocks are interbeded with quartzite, shale and limestone containing Middle to Late Ordovician conodonts (Nowlan et al. 1994). In the northern part of the belt, the Mosquito Lake Road volcanic unit consists principally of rhyolite and has yielded a late Cambrian U-Pb (zircon) age. Rocks of the New River belt plot in the same fields as those of this study on many discrimination diagrams, but tend to have lower $\mathrm{TiO}_{2}, \mathrm{Zr}, \mathrm{Nb}$, and REE compared to the Grand Manan Island samples (Fig. $7 \mathrm{~d}$ ). The relative depletion in $\mathrm{Ti}, \mathrm{Y}, \mathrm{Yb}$, and $\mathrm{Lu}$ in the Ross Island Formation is also present in the most mafic late Cambrian and late Ordovician rocks of the New River belt (e.g., samples 2G5, MLR10, Fig. 7), whereas more intermediate rocks (e.g. samples LTRI, $13 \mathrm{~A} 4$, Fig. 7d) more closely resemble rocks of the Ingalls 
Head Formation. Fyffe and Grant (2000), on geological grounds, preferred correlation of the Ingalls Head Formation with the late Cambrian Mosquito Lake Road volcanic unit, but the Mosquito Lake Road volcanic samples are geochemically more similar to those of the Ross Island Formation (Figs. 6, 7).

Moore et al. (1992) and Hodgins and Moore (1994) have argued that the $\mathrm{Nd}$ isotope characteristics of metavolcanic rocks of the Ross Island Formation, with $T_{D M}$ of $1.29 \mathrm{Ga}$, are unlike those of the Neoproterozoic Avalonian volcanic rocks (e.g. as summarized by Nance and Murphy 1996), although they fall well within the range of model ages determined in the Cobequid Highlands by Pe-Piper and Piper (1998). Hodgins (1994) reported $T_{D M}$ of $0.86 \mathrm{Ga}$ for a diabase in the Ingalls Head Formation (probably from the same unit as our sample 18). The $\mathrm{Nd}$ isotope data reported by Hodgins and Moore (1994) for the Priest Cove Formation indicate $T_{D M}$ of 1.6-2.2 $\mathrm{Ga}$. This age is substantially older than model ages for sediments derived from Avalonian volcanic sequences (e.g. Murphy and MacDonald 1993), but could be derived from Avalon-Gander basement of the type reported by van Staal $e t$ al. (1996). The bulk geochemistry of samples from the Flagg Cove and Long Pond Bay formations is, however, consistent with a derivation from an Avalonian source area (c.f. Murphy et al. 1996).

\section{CONCLUSIONS}

Andesite of the Ross Island Formation and dacite of the Ingalls Head Formation are derived by partial melting of hydrous mafic crust under moderate to low pressure ( $<8 \mathrm{kbar}$ ). The more mafic andesites of the Ross Island Formation may have formed in a residue containing olivine + orthopyroxene + clinopyroxene + amphibole \pm plagioclase $\pm \mathrm{Fe}$ - $\mathrm{Ti}$ oxide. The magma that formed the rocks of the Ingalls Head Formation seems to have equilibrated with a similar residue but dominated by pyroxene. High $\mathrm{Ti}$ in a mafic dyke in the Ingalls Head Formation is interpreted to reflect reducing conditions.

The Ross Island andesite resembles late Cambrian to late Ordovician volcanic sequences of the New River belt at the northern margin of the Avalon composite terrane, but no close geochemical analogue for the volcanic rocks of the Ingalls Head Formation has been found.

\section{ACKNOWLEDGEMENTS}

This work was funded by a Natural Sciences and Engineering Research Council research grant to Pe-Piper. We thank Malcolm McLeod for information he provided about the geology of Grand Manan Island and for making maps available to us. Dick Grant introduced us to the geology of Grand Manan Island. Les Fyffe provided helpful advice on stratigraphy and field relations. We also thank D.J.W. Piper for his help in the field and his reading of the manuscript. Reviews for the journal by Les Fyffe and an anonymous referee and the editorial advice of S.M. Barr resulted in substantial improvements to the manuscript.

\section{REFERENCES}

Alcock, F.J. 1948. Grand Manan, New Brunswick. Geological Survey of Canada, Map 965A (with marginal notes).

BARR, S.M. 1993. Geochemistry and tectonic setting of late Precambrian volcanic and plutonic rocks in southeastern Cape Breton Island, Nova Scotia. Canadian Journal of Earth Sciences, 30, pp. 1147-1154.

BARR, S.M., \& WHITE, C.E. 1988. Petrochemistry of contrasting late Precambrian volcanic and plutonic associations, Caledonian Highlands, Southern New Brunswick. Maritime Sediments and Atlantic Geology, 24, pp. 353-372.

BEARD, J.S., \& LOFGREN, G.E. 1991. Dehydration melting and watersaturated melting of basaltic and andesitic greenstones and amphibolites at 1, 3, $6.9 \mathrm{~kb}$. Journal of Petrology, 32, pp. 365401.

Chalot-Prat, F., \& Boullier, A.M. 1997. Metasomatism in the subcontinental mantle beneath the eastern Carpathians (Romania): new evidence from trace element geochemistry. Contributions to Mineralogy and Petrology, 129, pp. 284-307.

Drummond, M.S., \& Defant, M.J. 1990. A model for trondhjemitetonalite-dacite genesis and crustal growth via slab-melting: Archean to modern comparisons. Journal of Geopnysical Research, 95, pp. 21503-12521.

Feetham, M., Ryan, R.J., Pe-PiPer, G., \& O'Beirne-Ryan, A.M. 1997. Lithogeochemical characterization of the Beaverbank unit of the Halifax Formation, Meguma Group, and acid drainage implications. Atlantic Geology, 33, pp. 133-141.

FYFFE, L.R., \& GRANT, R.H. 2000. Geology of Grand Manan Island (parts of NTS $21 \mathrm{~B} / 10$ and B/15), New Brunswick. New Brunswick Department of Natural Resources and Energy, Minerals and Energy Division, Plate 2000-29.

Fyffe, L.R., Stewart, D.B., \& Ludman, A. 1988. Tectonic significance of black pelites and basalts in the St Croix Terrane, coastal Maine and New Brunswick. Maritime Sediments and Atlantic Geology, 24, pp. 281-288.

GILl, J. 1981. Orogenic Andesites and Plate Tectonics. Berlin, Springer-Verlag, $390 \mathrm{p}$.

GOULDEN, J.L. 1998. The origin of fluids producing barite and associated mineralisation in the western Cobequid Highlands, Nova Scotia [B.Sc. thesis]. Saint Mary's University, Halifax, N.S., $56 \mathrm{p}$.

Greenough, J.D., McCutcheon, S.R., \& PAPEZIK, V.S. 1985. Petrology and geochemistry of Cambrian volcanic rocks from the Avalon Zone in New Brunswick. Canadian Journal of Earth Sciences, 22, pp. 881-892.

HESS, P.C. 1989. Origins of Igneous Rocks. Harvard University Press, Cambridge, $336 \mathrm{p}$.

HILYARD, M. 1992. The geologic significance of Grand Manan Island, New Brunswick. [B.Sc. thesis] Hartwick College, Oneonta, N.Y., 26 p.

HodgINS, M.L. 1994. Trace elements, REE and Nd isotopic variations in metavolcanic and metasedimentary sequences, Grand Manan Island, New Brunswick. [B.Sc. thesis] Hartwick College, Oneonta, N.Y., U.S.A., 41 p.

Hodgins, M., \& MoORE, A. 1994. Trace element, REE and Nd isotopic variations in metavolcanic and metasedimentary sequences, Grand Manan Island, New Brunswick. Geological Society of America, Abstracts with programs, 26, p. 23.

IRVINE, T.N., \& BARAGAR, W.R.A. 1971. A guide to the chemical classification of the common volcanic rocks. Canadian Journal of Earth Sciences, 8, pp. 523-546.

JOHNSON, S.C., \& MCLEOD, M.J. 1996. The New River Belt: a unique segment along the western margin of the Avalon composite terrane, southern New Brunswick, Canada. Geological Society of America, Special Paper 304, pp. 149-164. 
Keen, C.E., Kay, W.A., Keppie, J.D., Marillier, F., Pe-Piper, G., \& WALDRON, J.W.F. 1991. Deep seismic reflection data from the Bay of Fundy and Gulf of Maine: tectonic implications for the northern Appalachians. Canadian Journal of Earth Sciences, 28, pp. 1096-1111.

LANDING, E. 1996. Avalon: Insular continent by the latest Precambrian. In Avalonian and related Peri-Gondwanan terranes of the Circum-North Atlantic. Edited by R. D. Nance and M.D. Thompson. Geological Society of America, Special Paper 304, pp. 29-63.

LUDMAN, A. 1987. Pre-Silurian stratigraphy and tectonic significance of the St. Croix Belt, southeastern Maine. Canadian Journal of Earth Sciences, 24, pp. 2459-2469.

MCLeOD, M.J., JOHNSON, S.C., \& RuITENBERG, A.A. 1993. Preliminary geological map, Grand Manan Island, sheets $21 \mathrm{~B} / 15,21 \mathrm{~B} / 14$, Campobello Island and $21 \mathrm{~B} / 10$, Grand Manan Island. New Brunswick Dept. of Natural Resources and Energy, Minerals and Energy Division.

MCLEOD, M.J., WINCHESTER, J.A., \& RUITENBERG, A.A. 1994. Geochemistry of the Annidale Group: implications for the tectonic setting of Lower Ordovician volcanism in southwestern New Brunswick. Atlantic Geology, 30, pp. 87-95.

MESCHEDE, M. 1986. A method of discriminating between different types of mid-ocean ridge basalts and continental tholeiites with the $\mathrm{Nb}-\mathrm{Zr}-\mathrm{Y}$ diagram. Chemical Geology, 56, pp. 207-218.

MOORE, A., Hillyard, M., \& DERRY, L. 1992. Grand Manan Island, New Brunswick: Avalonian marginal sequence or Paleozoic accreted terrane? Geological Society of America, Abstracts with programs, p. A238.

MURPHY, J.B., \& MACDONALD, D.L. 1993. Geochemistry and tectonic discrimination of Late Proterozoic arc-related volcaniclastic turbidite sequences, Antigonish Highlands, Nova Scotia. Canadian Journal of Earth Sciences, 30, pp. 2273-2282.

MurPhy, J.B., KePPIE, J.D., Dostal, J., \& HyneS, A.J. 1990. The geochemistry and petrology of the Late Precambrian Georgeville Group: a volcanic arc rift succession in the Avalon terrane of Nova Scotia. Geological Society Special Publication 51, pp. 383-393.

MurPhy, J.B., KePPIE, J.D., Dostal, J., WaldRon, J.W.F., \& CudE, M.-P. 1996. Geochemical and isotopic constraints on the accretion of Avalonia in the Appalachian-Caledonide orogen: evidence from the early Silurian clastic sequences in Antigonish Highlands, Nova Scotia, Canada. Canadian Journal of Earth Sciences, 33, pp. 379-388.

NANCE, R.D., \& MURPHY, J.B. 1996. Basement isotopic signatures and Neoproterozoic paleogeography of Avalonian-Cadomian and related terranes in the circum-North Atlantic. Geological Society of America, Special Paper 304, pp. 333-346.

Nowlan, G.S., MCCracken, A.D., \& MCLEOD, M.J. 1994. Tectonic and paleogeographic significance of Ordovician conodonts from the Letang area, Avalon Terrane, southwestern New Brunswick. GAC-MAC Program with Abstracts, 19, p. A83.

PEARCE, J.A., \& CANN, J.R. 1973. Tectonic setting of basic volcanic rocks determined using trace element analysis. Earth and Planetary Science Letters, 19, pp. 290-300.

Pearce, J.A., Harris, N.B.W., \& Tindle, A.G. 1984. Trace element discrimination diagrams for the tectonic interpretation of granitic rocks. Journal of Petrology, 25, pp. 956-983.

PE-PIPER, G., \& PIPER, D.J.W. 1989. The Upper Hadrynian Jeffers Group, Cobequid Highlands, Avalon Zone of Nova Scotia: a back-arc volcanic complex. Bulletin of the Geological Society of America, 101, pp. 364-376.

PE-PIPER, G., \& PIPER, D.J.W. 1998. Geochemical evolution of Devonian-Carboniferous igneous rocks of the Magdalen basin, Eastern Canada: $\mathrm{Pb}$ and $\mathrm{Nd}$ isotope evidence for mantle and lower crustal sources. Canadian Journal of Earth Sciences, 35, pp. 201-221.
Rankin, D.W., Drake, A.A., Glover, L., Goldsmith, R., Hall, L.M., Murray, D.P., RatclifFe, N.M., Read, J.F., SECor, D.T., \& STANLEY, R.S. 1989. Pre-orogenic terranes, In The Appalachian - Ouachita orogen in the United States. Edited by R.D. Hatcher, W.A. Thomas, and G.W. Viele. Geological Society of America, The Geology of North America, F-2, pp. 7100.

RAPP, R. P., \& WATSON, E.B. 1995. Dehydration melting of metabasalt at 8-32 kbar: Implications for continental growth and crust-mantle recycling. Journal of Petrology, 36, pp. 891-931.

Ruitenberg, A.A., \& MCCutCheON, S.R. 1983. Bedrock, surficial and environmental geology of North Head, Grand Manan. New Brunswick Department of Natural Resources, Geological Surveys Branch, Open File Report 83-1, 9 pp.

RUSHMER, T. 1993. Experimental high-pressure granulites: Some applications to natural mafic xenolith suites and Archean granulite terranes. Geology, 21, pp. 411-414.

SteRn, C.R., \& Kilian, R. 1996. Role of subducted slab, mantle wedge and continental crust in the generation of adakites from the Andean Austral Volcanic Zone. Contributions to Mineralogy and Petrology, 123, pp. 263-281.

STEVENS, J.E., MURPHY, J.B., \& ChANDleR, F.W. 1999. Geochemistry of the Namurian Lismore Formation, northern mainland Nova Scotia: sedimentation and tectonic activity along the southern flank of the Maritimes Basin. Canadian Journal of Earth Sciences, 36, pp. 1655-1669.

Stringer, P., \& PAJARI, G.E. 1981. Deformation of pre-Triassic rocks of Grand Manan, New Brunswick. Geological Survey of Canada, Current Research, Paper 81-1C, pp. 9-15.

Sun, S.-S and MCDONOUGH, W.F. 1989. Chemical and isotopic systematics of oceanic basalts: implications for mantle composition and processes. In Magmatism in the Ocean Basins. Edited by A.D. Saunders and M.J. Norry. Geological Society Special Publication 42, pp. 313-345.

TANOLI, S.K., \& PICKERILL, R.K. 1988. Lithostratigraphy of the Cambrian - Lower Ordovician Saint John Group, southern New Brunswick. Canadian Journal of Earth Sciences, 25, pp. 669690.

TAYLOR, S.R and MCLENNAN, S.M. 1985. The Continental Crust: Its Composition and Evolution. Oxford, Blackwell Scientific, 312 p.

Trembath, L.T. 1973. Zeolite mineral assemblage, Grand Manan Island, New Brunswick. In Geology of New Brunswick: Field Guide to Excursions (1973 NEIGC). Edited by. N. Rast. University of New Brunswick. pp. 1-3.

van Staal, C.R., Sullivan, R.W., \& Whalen, J.B. 1996. Provenance and tectonic history of the Gander zone in the Caledonian/Appalachian orogen: Implications for the origin and assembly of Avalon. Geological Society of America Special Paper 304, pp. 347-367.

Wade, J.A., Brown, D.E., Traverse, A., \& Fensome, R.A. 1996. The Triassic-Jurassic Fundy Basin, eastern Canada: regional setting, stratigraphy and hydrocarbon potential. Atlantic Geology, 32, pp. 189-231.

WILSON, M. 1989. Igneous Petrogenesis. London, Unwin Hyman, $466 \mathrm{p}$.

WINCHESTER, J.A., \& FLOYD, P.A. 1977. Geochemical discrimination of different magma series and their differentiation products using immobile elements. Chemical Geology, 20, pp. 325-343.

YOGODZINSKI, G.M., KAY, R.W., VOLYNETS, O.N., KOLOSKOV, A.V., \& KAY, S.M. 1996. Magnesian andesite in the western Aleutian Komandorsky region: Implications for slab melting and processes in the mantle wedge. Bulletin of the Geological Society of America, 107, pp. 505-512.

ZEN, E.A. 1983. Exotic terranes in the New England Appalachians limits, candidates, and ages: A speculative essay. In Contributions to the tectonics and geophysics of mountain 
chains. Edited by R.D. Hatcher, H. Williams, and I. Zietz. Geological Society of America, Memoir 158, pp. 55-81. 